\title{
A Narrative Self-Study of Advocacy by an Educational Practitioner with Multiple Roles
}

\author{
Mary Rice \\ Brigham Young University
}

\begin{abstract}
This self-study follows my work on three professional knowledge landscapes (Clandinin \& Connelly, 1996). It was an effort at revealing both my knowledge-in-practice and knowledge-ofpractice (Cochran-Smith \& Lytle, 2004) in order to uncover understandings about my own use advocacy as a classroom teacher, a new teacher mentor, and a teacher educator on a university campus. Through the course of the study, my attention turned toward my own use of advocacy as a classroom teacher, a new teacher mentor, and a teacher educator on a university campus-the places where tensions occurred. Advocacy experiences in all three of these roles tended to be dependent on maintaining a delicate balance of positioning between myself, the student, the new teacher, or mentee, and another school official. I was also able to see the ways my personal practical knowledge was lived in and out in the various situations.
\end{abstract}

Keywords: Terms: teacher, teacher educator, new teacher mentor, advocacy, speech acts, social capital

Mary Rice teaches at Springville Junior High School and Brigham Young University. Her research interests are advocacy, teaching English language learners, and adolescent literacy. Email: mary.rice@nebo.edu

Brock Education, Volume 18, No. 2, Spring 2009, 16-28 


\section{A Narrative Self-Study of Advocacy by an Educational Practitioner with Multiple Roles}

This narrative self-study follows my work in three professional knowledge landscapes (Clandinin \& Connelly, 1996). It was an effort at revealing both my knowledge-in-practice and knowledge-of-practice (Cochran-Smith \& Lytle, 2004) in order to uncover understandings about the ways in which I negotiate these landscapes.

\section{Current professional context}

The professional roles that served as subjects for this self-study were:

1. Classroom teacher - I teach language arts at a suburban junior high school. I also teach the English Learners in the school and monitor them in a joint effort.

2. New teacher mentor-I am in charge of up to five new teachers per year who are in their first three years of teaching. My responsibilities are to help them become accustomed to our school, develop a teacher identity, and qualify for a tenured license at the end of their three probationary years.

3. University instructor-I teach up to two sections of any of the six courses in the teaching English as a second language endorsement program.

I found myself in three-dimensional narrative inquiry space, experiencing the tensions involved in trying to stand simultaneously in the professional knowledge landscapes (Clandinin \& Connelly, 1996) of a classroom teacher, as well as the space belonging to teacher educator. As a classroom teacher, my commitment to improving the learning experiences of children can be examined in relatively concrete terms. We are together every day and I own the practices that I enact in my quest to educate them. Although I do not believe that the relationship between teaching and learning is necessarily causal, I do think that the fact that I interface directly with these children positions me to provide direct opportunities for students to have experiences that result in learning.

As a teacher educator, my ontological commitment to helping children have good learning experiences shifts as I am trying to help prospective teachers consider ways to be agents who can facilitate [learning] opportunities for students they will have in their classes. For the teacher educator, the children usually exist only in theory; but for the prospective teacher, those children will eventually exist in practice. Therefore, my ability to judge whether I am meeting my goal of helping children to learn is much more difficult to assess as a teacher educator, but I worry about this goal nonetheless because I have children in my classroom who need competent teachers. Teacher educators not currently teaching K-12 students may derive their commitment from the students they had in the past. The tensions between these landscapes emerged when I was asked to mentor new teachers at my school. In this role, my concrete commitment to children was present and comes from the fact that I have some of the same students as the colleagues I was mentoring in my class or will potentially have them in the future. In addition, both my mentees and I teach in the same physical space. Simultaneous to this responsibility, I need to be committed to my mentees' students in the present and those in the future. 


\section{Review of literature in the context of my development as a teacher}

I reviewed the literature concerning advocacy in the narrative voice using an organizational timeline of how I developed as a teacher, teacher educator, teacher mentor, and recently teacher researcher in terms of advocacy.

\section{Living History}

During my first year teaching in the endorsement program, I came to read Living History, the autobiography of Hillary Clinton (2004). The autobiography is a defense of some of Clinton's public actions based on a definition of "politician" versus "advocate." A politician, Clinton argued, has to make compromises based on a hierarchy stemming from the greater good. Advocates, on the other hand, even if you gave them everything they asked for, they would never be satisfied. According to Clinton, the difficulty is balancing when to be a politician and when to be an advocate.

Beginning in my early days as a new teacher, not remembering receiving any training on being an advocate other than the admonishment to be so, I used Clinton's (2004) definition as a frame. I decided that I wanted to direct most of my efforts at advocacy. To me, advocacy carried a higher moral imperative than politicking did, but I was rarely able to walk away from experiences where I employed the advocate frame, as Clinton defined it, with any feeling of accomplishment when every conversation I entered into was one where I could never be satisfied. Not surprisingly, I have abandoned this orientation as a tool.

\section{Social Capital}

When I became involved in preparing teachers to work in classrooms, it was an imperative for me to find a way to discuss advocacy so that the prospective teachers I was working with would not run into the same uncertainty I experienced. I was especially motivated to consider issues of advocacy in my work with English Learners - a population I believe is in need of advocates in schools. In the midst of this pursuit, I studied the work of Putnam (2001), who proposed that communities strengthen in the presence of social capital. According to Putnam, successful social systems emerge from human relationships predicated on the notion of generalized reciprocity. In other words, I should do things for other people first with the trust that they would assist me if I needed it, but there cannot be any ultimate and specific expectation involved. In exploring the concept of social capital, I came to realize that I could strengthen the efficacy I have on all of my professional knowledge landscapes and actualize my goals in all of my roles. Social capital building carries a satisfactory moral alignment that I was not finding in politicking alone, and does not require permanent dissatisfaction like the definition of advocacy promoted by Clinton (2004). I wanted to share some of these ideas with my prospective teachers, but it does not allow me to be specific in describing the nature of my experiences.

\section{Finding Ways to Name Stories in a School Landscape}

I also discovered a language for discussing events in schools in the work of Clandinin and Connelly (2000). These authors suggested that borrowing language from literary analysis, such as plotline, is potentially helpful in depicting events in schools. They also suggested discussion- 
promoting language such as "conflicting story" to describe plotlines that result in negativity or mistrust in schools and "competing story" to describe plotlines that are still in tension, but can coexist. I have found Clandinin and Connelly's (2000) language helpful in discussing space, place, and time using the metaphor of a professional knowledge landscape that centers on school. Experiences in schools can be conceived as plotlines that are influenced by many factors and are related to one another in complex and shifting ways from both moral and intellectual standpoints. Plotlines are built around significant experiences that come to define beliefs about an event or phenomena. These plotlines are central to the discourse around positioning as well as narrative inquiry

\section{Positioning Theory}

According to Searle's work in speech acts (1970), when we say something, we really do something. There are direct speech acts as well as indirect speech acts, but both types accomplish a task. When I was a new teacher, I was constantly worried that I was not able to improve the experiences of children in the ways that I wanted. Additional stress came from not knowing why I was failing. By employing positioning theory (Harré \& Van Langenhove, 1999), I was able to analyze what was happening in the conversation at a sociolinguistic level.

The process of speaking to other people is rich in both obligations and responsibilities for all parties involved. The way in which we assume and delegate those rights is called "positioning." A position is derived from, while at the same time interacts with, two sources: the plotlines we have about ourselves or the subject matter of the conversation and the social or illocutionary force derived from our demeanor or some other legitimate source. The interplay between these three forces (position, plotline, and illocutionary force) interfaces with the other speakers. When a conversation takes place, these forces may diminish, amplify, or remain essentially constant for all parties involved.

According to Harré and Van Langenhove (1999), most speech communication is relational and in order for one person to be positioned as powerful, the other has to be positioned as powerless or not as powerful. In my experimentation with speech acts, however, I learned that I have more power as an advocate when I position students and colleagues in the more powerful position. Inserting students more directly in the conversation encourages me as well as others to reopen plotlines about why a tension exists and then to decide if the tension results from a competing story or a conflicting one.

\section{Method}

This narrative self-study inquiry is partially grounded in the five characteristics of self-study as outlined by LaBoskey (2004). According to LaBoskey, self-studies should be self-initiated, interactive, aim for improvement, qualitative, and exemplar-based. My study was self-initiated: it was rooted in my local, situated, and contextual circumstances, but rather than being a study of the researcher only, it is a study of the teacher researcher's practice, and includes others, specifically my colleague, the teacher educator, and the positioning and narrative frameworks, which informed my analysis, which also makes the study interactive. The interaction is couched in an aim for improvement, which concern typically animates self-study. My own confidence to analyze my actions with others has greatly increased. In addition, public knowledge of improvement provides opportunities for others to improve as well. Discussing my experiences 
with a colleague helped me understand my practice and my impact on the climate in these spaces. My previous training in qualitative ethnographic research, particularly in regards to the folklore field also contributed to data collection as well as interpretation. According to cultural anthropologists, ethnography requires that holistic measures be used to interpret experiences because constituent parts are not adequate to convey experiences. The research reported here derives exemplar-based validity from exploring narratives that are emblematic of the narratives from my field notes. The selected exemplars are considered by the researcher in concert in order to frame conclusions and surmise implications for making my own practice problematic and "thus stand in a different relationship to knowledge and action" (Cochran-Smith \& Lytle, 2004, p. 614).

I became interested in capturing and making sense of my experiences as a teacher, a teacher educator and a teacher mentor. The methods that I employed emerge from both the narrative inquiry methodology, as well as self-study methodology. Across seven months, I created field notes, recorded my experiences, collected artifacts, and determined where my plotlines from each of my three professional knowledge landscapes were intersecting with one another. Other techniques from the self-study methodology include autobiographical methods in the form of journaling and correspondence. Bullough and Pinnegar (2001) provided guidelines for quality in self-study in using these forms. Specifically, they asserted that, in order to help establish the trustworthiness of the study, journaling and correspondence should provide the reader with insight into what the author of the self-study is thinking and feeling, in addition to interrogating relationships, and revealing complications or tensions (pp. 19-20). Considering these guidelines, I began collecting and then analyzing all of my conversations and correspondences related to advocacy in the three roles I decided to focus on. I also made field texts of my realizations and the development of my thinking as I engaged in the collection process. Adding to these field texts, I also included the documentation of relating sharing and dissecting those experiences with a colleague who is a teacher researcher and who comes to my classroom at the junior high regularly. This practice of collaborating with a colleague is in the tradition of Loughran and Northfield (1996), where Northfield shared his data with Loughran, for review and critique.

While I was trying to establish which narratives were emblematic, I found myself also inclined to recapture experiences that I had as a new teacher. It occurred to me that these experiences shaped the ways in which I framed advocacy within the roles of teacher educator and teacher mentor. By capturing my own experiences, I was now able to reveal to myself what my plotline really was, versus what I believed it was prior to engaging in the study. I selected my narratives, captured relevant autobiography, and then used those two together to determine my plotline for myself as a teacher educator and a teacher mentor. I applied positioning theory to my emblematic narratives from those two roles first, and then to my experience I had selected from my role as a classroom teacher, even though they are presented in reverse order here.

The process of analysis, interpretation, selection, and revision of my experiences is based on narrative inquiry methodology as defined my Clandinin and Connelly (2000, 1997, 1996, 1992). The process of developing initial understandings came about by retelling my stories, which made it necessary for me to reconsider their experiential components. In order to reconsider in a manner faithful to narrative inquiry, I had to relive the experience as well and record my inner responses. After exploring the narratives in this manner, I built a review of literature in advocacy that focused on sociolinguistics, and I chose positioning theory (Harré \& Van Langenhove, 1999) as a way to talk about advocacy when it enabled me to re-imagine 
plotlines as a part of advocating. I extracted a theme from my experiences and considered narratives to serve as exemplars. Eventually I chose a narrative from each role that fit both my plotline in that role and represented the dominant plotline of those experiences.

Employing methods from both the self-study and narrative inquiry methodologies enabled me to describe my experiences in ways that are more substantial. The thickness that resulted interacted with my research question, causing it to become more refined, which caused my purpose to become more refined as well. It also became clearer that techniques from both methodologies would be most useful in guiding my research and helping me develop assertions for understanding and action. In this sense, purpose illuminated method and method illuminated purpose.

\section{Emblematic Narratives}

What follows are the three emblematic narratives — one from each role — with my accompanying analysis, using the tools from my literature review. My descriptions and discussions of the tools vary in weight according to my own understandings of the tools and my present ability to reflect on them.

\section{Role 1: Classroom Teacher}

As a classroom teacher, I believe I have a duty to ensure that my students are having positive and fair interactions with administrative officials and other teachers, particularly in terms of discipline. When students are disciplined unethically it shows up in my classroom: student dispositions change. When students have to miss class to be disciplined, there is the potential that academic progress will be impeded.

Additionally, my students believe that I have legitimate power, which is a critical component of positive classroom management. One product of this management style is that students will intentionally position me as a person of power in the school. Their asking me to inquire on their behalf confirms my social dominance over them as an adult and as a professional. It also puts me in a social position where I have to prove that I have power. The hidden plotline is that if I cannot help them, I have no social standing. If students believe that about me, it has the potential to change their orientation towards me in the classroom and affects the way their story about me will be recalled and retold after they leave my classroom.

Justin entered my language arts class as an eighth grader towards the end of the year while I attended a conference. He has a twin sister who was assigned to a colleague of mine for language arts. Justin knew that he was supposed to be in a different class than his sister, but he also thought those classrooms would be close to each other, which was incorrect. My classroom is farther down the hall. Justin went to the wrong language arts class and was not aware of it. When I returned from the conference, I saw his name on my roll and realized he had not been coming to class. I went to look for him and found that he had been attending the wrong class. Later that day, I restored him to my class. The next fall, Justin had been assigned to my grade nine classroom. During the last period of the day at my school, detention slips are handed out. One day while passing out these slips, I realized Justin had been issued detention for not reporting to one of his classes. I questioned him about this because not attending class seemed out of character for him. He explained to me that he accidentally went to the wrong lunch and

${ }^{1}$ All students and colleagues have been assigned pseudonyms. 
was barred from going to the right class by another teacher. Apparently, this teacher, who was doing his job in monitoring the students, also had a plotline that students who want to use the hall usually have mischievous reasons for doing so. Justin's explanation of these events to me was not merely to position himself as a victim and me as a caretaker. Initially, I believe all he wanted to do was position himself as a truth teller to himself and have me confirm his veracity. He had served the detention for this act. Several days later, however, he got a notice to serve more detention and only then, did he make an actual appeal to me. I had to reposition myself with the detention supervisor in order to get a resolution, which was that he would only be committed to time served since she had made an error in assigning him only 30 minutes for the cutting class offense, which normally was assessed a 60 minute detention penalty. Below is a series of personal emails between the detention supervisor and myself where I try to reposition Justin as a truth teller and get the detention supervisor to interact directly with him. After each email I elaborate on the context and explain my reasoning.

\section{Thu, 25 Oct 2007 \#1}

Justin got a sluff ${ }^{2}$ and so he got a green slip to serve for 30 minutes. He swears

that he served the detention already but he continues to receive slips. Can you talk to him if you think he still needs to serve or let me know that it is fixed?

Mary Rice

I performed this negotiation without telling her that the charge that Justin intentionally missed class may not have been whole truth in the first place in order to maintain my position of collegial equality with her. When she emailed me back, she confirmed that there would be only 30 more minutes to serve. Her brevity may be an attempt to position herself as an authority (i.e., a decision had already been made and is irrevocable).

\section{Thu, 25 Oct 2007 \#2}

He only served for 30 minutes. He has 30 more minutes to go.

Thanks, Mona

In my reply to her I revealed more details about how he received a paper that said he had only 30 minutes and asked for one more confirmation that the 30 minutes was all that was left. I reiterated my plotline, which also served as a competing story that Justin was not trying to get out of detention, but he was concerned.

\section{Thu, 25 Oct 2007 \#3}

That makes some sense, but the original paper he received said that he only had 30 minutes, so that is why he thought he was done. So 30 more minutes and that is it?

Mary

This time the detention supervisor was willing to speak with Justin, whereas her first email where I suggested she speak with him received no reference. Her apparent commitment to speak with Justin was accompanied by a willingness to address his original detention notice.

\section{Thu, 25 Oct 2007 \#4}

Have him come and talk to me on Monday. I cannot get into the SIS program from home and I don't have the papers with me. Better yet, just tell him he is done and I'll clear it out where he thought he was finished.

Thanks, Mona

In the email to me where she clears Justin's detention, her plotline matches the teacher that refused to let Justin go to class when he discovered he had gone to the wrong lunch - that is

${ }^{2} \mathrm{~A}$ "sluff" is the term used in the region where I live to describe the intentional missing of school. 
that Justin's first instinct is to lie. The stories of these two professionals work in concert to support a dominant narrative about junior high students in general - that they do want to follow directives about when to go to class. In contrast, my plotline about Justin is that he is a shy teen who desires to tell the truth. He was even willing to serve the fraudulent detention until he was assigned more minutes and he could not foresee where that would end. I arrived at my narrative about Justin based on my experience with him, which was also influenced by my own narrative about the nature of junior high students. I think young people at this age generally would like to do what adults ask. When students are non-compliant, they were not given sufficient instructions, lacked the supplies they needed, or their biology would not let them comply. In this case, I believed Justin's development caused him to be distracted and so he did not end up where he needed to be. Most adolescents are easily sidetracked, but some are more so than others are. In my classroom experiences with Justin, this happened often. Therefore, when I found out he had gone to the wrong lunch, I was convinced it was just a manifestation of his personality. In a way, it also confirmed that I was correct in my assessment of him, and he was not just easily distracted in my class.

\section{Fri, 26 Oct 2007 \#5}

Let him know that if he sluffs again, that I will add the time of 30 minutes back on. That should help him to not sluff again???? Anyway, we hope right? Thanks, Mona

Leaving out the fact that the detention may not have been justified in the first place helped me to concentrate on the situation where Justin received notice to serve 30 minutes, served the time, and then was assigned 30 more without an explanation. Instead of drawing attention to the difference in our plotlines, thus creating a conflicting story, I concentrated on her gesture of solidarity, extending from her use of "we" in the final sentence. In response, I extended to her the power in this situation by calling attention to her goodwill. In this instance, I both drew on, and then built social capital with her.

\section{Thu, 25 Oct 2007 \#6}

Alright, I will tell him that he is done. I am sure he will be excited to hear that. You are very generous.

Mary

\section{Role 2: New Teacher Mentor}

One of my duties as new teacher mentor is to listen to the concerns of the new teachers as they come up. Most new teachers, however, are uncomfortable telling stories about themselves that are not positive while they are still forming their teacher identities. According to Clandinin and Connelly (2000), teachers often learn to censor their stories for political reasons, which results in cover stories. However, I think that it is important for new teachers to be able to interpret, not just the story, but the cover stories as well. Therefore, it is important to establish a professional rapport with them through social capital building. One interesting thing I have noticed in my mentoring is that I am quick to find growth in their stories to me that they consider negative, but when I have similar experiences, I interpret them as failures. Working with new teachers, therefore, has brought to my consciousness the experiencing of noticing and reinterpreting my own experiences the way that I would for a mentee.

Another web of stories that affects my work as a mentor is my own experiences as a new teacher. Particularly during my first year, I was often frustrated. I endured the constant dilemma 
of not knowing what to do, and I did not perceive the advice as being helpful. In the end, the most important support was my husband (who is also an educator), and my mother-in-law (who is not involved in education, but has been married to my father-in-law, who is, for almost 40 years). These people were willing to listen to me. I could talk about the same experience repeatedly and they continued to listen to stories from my teaching and allowed me to reinterpret them. Instead of advice, their comments were more directed towards giving me opportunities for reliving and retelling, which caused introspection and reflection. The most empowering thought I have developed over the years, which is probably based on these interactions, is that I am responsible for what happens in my classroom. If I can accept responsibility, then, I have tremendous power for authoring a new story. If I own the narrative, I can re-write it.

It was in this context that I oriented myself towards mentoring. To this end, my mentoring partner and I invited all of the new teachers to a barbecue at the beginning of the year. I also started eating lunch in the faculty room and encouraged my first year teacher, Caleb, to attend. During this time, I made a point to relate my own ironic and anti-hero stories to position us as collegial equals. After one of our mandatory new teacher meetings, Caleb lingered to talk and related a story to me. In his seventh grade art class, Caleb had shown his students Les Dammes d'Avingnon by Pablo Picasso. This abstract painting is also called, "Five Naked Ladies." In explaining the piece to the students, Caleb used the English nickname, instead of its original French one and a parent called the principal to complain about his child having been exposed to pornography. The principal defended Caleb to the parent, stating that the painting was abstract and Five Naked Ladies was not its real name, among other things. He then told Caleb not to show that picture anymore, even though there was nothing wrong with it. Naturally, Caleb was confused.

While listening, I attempted to maintain my position as a sympathetic mentor, but I also needed to provide an opportunity for him to grow so that he did not encounter the same circumstances again. I have a moral obligation as well as a professional one to help him become a reflective practitioner. While I was making the decision about what to say to Caleb, the tension of helping him avoid professional jeopardy competed with my own experience as a new teacher who was not interested in advice when I got into trouble, however much I wanted the trouble to go away. When Caleb finished his story, I asked him what he planned to do now, so that this did not happen again. He was stunned shortly, but then he began to brainstorm things he could dobesides merely deleting the painting with the objectionable name from his curriculum. As Caleb brainstormed, he began to increase in his enthusiasm for his newfound power and my own confidence in Caleb's ability to overcome glitches in his teaching through reflection grew as well. I found myself admiring the swiftness with which he was able to recover and wondering whether I would have been so resilient in a similar situation. In the following months, Caleb and I used reliving and retelling to improve his classroom management and grading system. My attempts to position Caleb as competent by opening a plotline where he had responsibility, and therefore power, was not merely an attempt to help Caleb grow. On some level, I was seeking to redeem myself from my perceived faults as a new teacher. This realization served as a signal that I was going to have to think more deeply about my motivation for being a mentor and for my actions while mentoring.

Although I am no longer Caleb's mentor he still comes to sit with me at lunch to exchange stories about teaching. He also asks me about administrative directives that he does not understand. I felt gratified that even though I no longer have an official professional 
responsibility for him, that Caleb still allows me to care about him and support him in growth as teacher. One interpretation of Caleb's continued contact with me is that Caleb is not yet an independent teacher and continues to seek my support. Another interpretation is that I supported him in his pre-existing disposition to relive and retell; I positioned him to open up a plotline where lived experience was valuable. To me, the effort that Caleb has made to seek me out to share stories suggests professional interdependence and a sustainable milieu for growth throughout his career. It also shows that Caleb and I have built some social capital together-our story sharing represents generalized non-reciprocity. We do not consider we owe one another for assistance in reliving and retelling.

\section{Role 3: University Instructor}

In December of last year I heard from a former student from the university. She felt that she was being forced to suppress her previous self-positioning as a competent teacher when her district imposed a restrictive, one-size-fits-all educational program for the ELs she was working with at her school. Her contacting me put me in a deliberate position-she was asking me directly what she should do with the implication that I could either solve the problem for her personally or even solve it permanently at her school. My initial reaction was concern for my former student. I wanted her to have a good teaching experience so that she would stay in the profession and so that her psychological well-being could be preserved.

My second point of concern was for her students. Her communication to me revealed that her angst was not based on her own comfort, but in the fact that she did not feel at liberty to enact her training and that the program she was forced to deliver was detrimental to the students' academic success. Her contact with me seemed to reveal that her teacher training might have prepared her in terms of theory and practice, but not policy. I wondered what her troublesome situation revealed about my teaching of her. While she was my student for only one class during one semester, her experience still made me question what I could be doing to prepare teachers for the various political climates where they will teach. It also made me wonder about whether the current conversations that I have with students about social capital will be sufficient, since this student was in my class before I had developed any strategies. I also discovered that I was also lacking confidence in helping a student to handle policy myself. If I could not figure out how to navigate this situation, how could I ever help students to do so? The layering of the experience I was having was complicated. Essentially, I was engaging in advocacy for helping someone else learn to advocate and I knew that just telling her to advocate would not be enough.

In the middle of this dilemma, I was also aware that I had no authority whatsoever in her district and therefore, my options were limited. I elected to contact some of the personnel in that district that I had met previously to voice the concerns that they were in jeopardy of losing an outstanding new teacher. I tried to suggest that we have responsibilities to help new teachers adjust, regardless of whether we can make sweeping policy changes based on their comfort. I also exerted some social capital by emailing the person I knew from the university where I worked who gave me the name of another person directly in charge of English language instruction. I sent an email to both these officials and received no reply from either.

While waiting for the responses that never came, my thoughts turned on several occasions to a story from my personal plotline that was similar to my former university student's plotline. At that time, I was working as educational support personnel with ELs in a different school district while I was still pursuing my teaching degree. I encountered tension in the way 
that I was being taught at the university and the enacted curriculum in the school where I was working. Although I was not yet a teacher, I made the decision to quit this position. Soon after, I found work in a school with ELs and no program. In this school context, I could construct a program for ELs with a dominant narrative about second language acquisition that more closely matched my own. Remembering my own satisfaction in my new situation coupled with the feeling that I betrayed students at the old school by leaving, I proceeded to try to empower my former university student with the knowledge that she could quit, or she could endure with the assurance that either way I would listen and support her.

My attempts to position myself and utilize my social capital on her behalf appeared to have failed completely. However, I continued to worry about this student as well as the students she was teaching. It was not for several months that I decided that while I had no apparent social capital with the school officials in that other district, I did with my former student, which is why she emailed me. I decided that I should have emailed her and tried to comfort her in her bereaved position. In an attempt to ameliorate this oversight, I sent the following email where I revealed my plotline for myself as a teacher and for my students, hoping that she would in turn be empowered herself. I engaged in deliberate intentional positioning as someone who had been through similar discordance in my early teaching experience. In the future, my alignment has become to assert social capital where I have it, instead of attempting to assert an illocutionary force that I already know that I do not have.

\section{Wed, 30 Jan 2008}

I feel very sorry for you in this unfortunate situation where you feel you are forced to teach in a way that is incongruent with your training. When this situation happened in my life I had to make a very tough decision about whether to continue in my current post or to seek employment in another place where I would be able to live out the story I wrote for myself about what kind of a teacher I wanted to be. I felt bad leaving and I worried about my students. Therefore, what I am saying is you have a grueling decision to make, and no matter what you decide, I have so much faith in you and your ability to touch lives that you will be a powerful person in the lives of young people no matter what your curriculum is. I have colleagues come into my class all the time trying to figure out what it is that I am doing with my curriculum that makes students enjoy my class so much (I have a waiting list to get in it.) They miss the fact that my curriculum is not particularly special (even though it is sociocultural). What is different about my class is the abiding unabashed individualized love that I have for each and every kid. And that carries me through the times that I feel the bureaucratic weight of educational oppression looming over me. I know you love your kids. You are taking many risks to try and advocate for them.

I would really like to keep hearing from you, no matter what you decide. You are such a good person and gifted teacher. I am so lucky that I have the opportunity to work with you. Please keep in touch and let me know if you need anything like a letter of recommendation or continuing emotional support. I will assist you to whatever level my power and person can bear.

Mary Rice

This experience was rife with learning opportunities for me. From my previous experience as a teacher educator, I was aware of the tension in teacher education between meeting the needs of the learners and meeting the needs of the teacher candidates. My experience in schools also brought me into the awareness of the tension involved in telling supervisors that 
their students have needs they do not think are being met. What I was not prepared for, however, was the tension embedded in my belief that I can stand simultaneously in multiple professional roles when others do not believe that I can. The lack of response to my emails could have come from this tension. When I am advocating as a teacher-educator, it is possible that I am only seen as a teacher. When I am advocating as a teacher, it is possible that I am only seen as a distant someone from a university. While it seems that the role of teacher and teacher mentor have not seemed to cause particular conflict, the roles of teacher and teacher educator are disconnected and may be understood as competing stories, stories that may be sustained, but with some tension. However, since this teacher is already teaching, maybe it was in fact the roles of teacher mentor and teacher educator that were not recognized by the district personnel. Either of these positions provides a potential rationale for why I was ignored. Of course it is always possible that my emails were never read or that the supervisor was distracted and forgot to answer.

When this student emailed me back, she had notified the Office of Civil Rights about the illegalities of the situation she had been working in, and was planning to leave teaching to go to law school to use the legal system to improve instruction for ELs. I agreed to meet with her at the university and together we looked for programs that might be suitable for her and identified contacts for several programs. In the course of our conversation, she solicited emotional support in addition to vocational advice. When we parted, she was positive about her new direction. I was still concerned about her as a teacher who was planning to leave education, having had a poor experience, but who still wanted to impact student lives. I wondered what the possibility of her being able to accomplish her goals for improving the education of ELs from outside the classroom and even the school context.

\section{Pushing Positioning Boundaries}

This narrative self-study inquiry highlighted possibilities in my roles of teacher, teacher mentor, and teacher educator for retelling and reliving. These possibilities for retellings and relivings occurred for the individuals and me in relation to the different roles. At various times I understood my narratives and the narratives as others as competing or conflicting. It was over time that these narratives shifted from competing to conflicting, although in some cases they also shifted from conflicting to competing as in the case of Justin. In all of these examples I was able to see the ways my personal practical knowledge was lived in and out in the various situations.

When I engage in speech acts with a goal of opening a plotline for an individual that I believe has power, and therefore, responsibility, I am more likely to engage in competing stories, instead of conflicting ones. Sometimes, as with Justin and the detention debacle, my attempt to open the plotline was to avoid capitalizing on our divergent plotlines about Justin's motivation. With my mentee, I engaged in neutral questioning with the intention of good will. For my former university student, I shared part of my personal experience with a similar problem to hers and I revealed my plotline about myself as a teacher. I also find that advocacy is one issue in teaching where those who engage in it have to continually re-imagine and re-open their own narratives about how they became a teacher, and what the purpose of education really is. While interrogating these issues can be uncomfortable for me, I also find that doing so is the surest path to new understandings for me and my students. 


\section{References}

Bullough, R.V. Jr., \& Pinnegar, S. (2001). Guidelines for quality in autobiographical forms of self-study. Educational Researcher, 30(3), 13-22.

Clandinin, D. J., \& Connelly, F. M. (1992). Teacher as curriculum maker. In P.W. Jackson (Ed.), Handbook of research on curriculum (pp. 363-401). New York: Macmillan.

Clandinin, D. J., \& Connelly, F. M. (1996). Teachers' professional knowledge landscapes: Telling stories - stories of teachers - school stories - stories of schools. Educational Researcher, 25(3), 24-30.

Clandinin, D. J., \& Connelly, F. M. (1997). Asking questions about telling stories. In C. Kridel (Ed.), Writing educational biography: Explorations in qualitative research (pp. 202-209). New York: Garland.

Clandinin, D. J., \& Connelly, F. M. (2000). Narrative inquiry: Experience and story in qualitative research. San Francisco, CA: Jossey-Bass.

Clinton, H. (2004). Living History. New York: Scribner.

Cochran-Smith, M., \& Lytle, S. L. (2004). Practitioner inquiry, knowledge and university culture. In J. Loughran, M. L. Hamilton, V. LaBoskey \& T. Russell (Eds.), International Handbook of Self Study of Teaching and Teacher Education Practices (pp. 601-649). Dordrecht: The Netherlands: Kluwer Academic Publishing.

Harré, R., \& Van Langenhove, L. (1999). Positioning Theory: Moral Contexts of International Action. Oxford, England: Blackwell.

LaBoskey, V. (2004). The methodology of self-study and its theoretical underpinnings. In J. Loughran, M. L. Hamilton, V. LaBoskey \& T. Russell (Eds.). International Handbook of Self Study of Teaching and Teacher Education Practices (817-869). Dordrecht: The Netherlands: Kluwer Academic Publishing.

Loughran, J., \& Northfield, J. (1996). Opening the Classroom Door: Teacher, researcher, learner. London: Falmer.

Putnam, R. (2001). Bowling Alone: The Collapse and Revival of American Community. New York: Simon \& Schuster.

Searle, J. (1970). Speech Acts: An Essay in the Philosophy of Language. Cambridge University Press. 